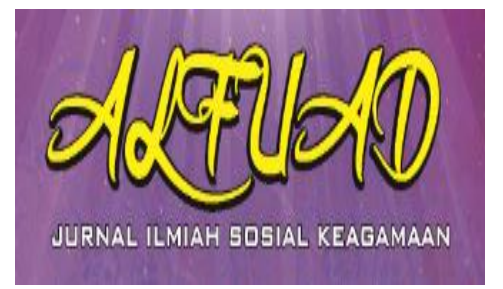

ALFUAD JOURNAL, 2 (2), 2018, (48-58)

(Print ISSN 2614-4786)

Available Online at

http://ecampus.iainbatusangkar.ac.id/ojs/index.php/alfuad

\title{
SENI TARI DALAM PANDANGAN ISLAM
}

\section{Tri Yuliana Wijayanti}

Institut Agama Islam Negeri Batusangkar Indonesia

E-mail: tri.yw@iainbatusangkar.ac.id

\begin{abstract}
Humans in their daily lives cannot be separated from art. Art is a form of aesthetic expression towards human existence as a servant. Expressions of beauty that are expressed through beautiful movements, will give birth to exotic dance. Speaking of dance, in general, the negative prejudices of both dancers and dances are generally generated. This is interesting to study when drawn with the flexibility of Islamic teachings and the core of Islamic teachings themselves, namely tauhid.
\end{abstract}

Keywords: Art, Dance, Islam

\section{PENDAHULUAN}

Islam adalah agama yang diturunkan oleh Allah SWT melalui Nabi Muhammad saw sebagai jalan hidup bagi seluruh makhluk. Melalui pengamalan nilai-nilai yang dikandung Islam, manusia diharapkan mampu mewujudkan fungsi inti dari penciptaan manusia, yaitu sebagai 'abd yang kemudian ditransformasikan dalam kehidupan sebagai khalifatullah fil-ardl agar terwujud rahmatan lil 'alamin.

Allah menciptakan manusia beserta fungsi dan peran yang harus dijalankannya di muka bumi. Dalam tahap struktural, alQur'an menyebut manusia sebagai nafs atau ego yang terbentuk dari unsur jasad yang kemudian terwujud dalam perantara sebagai hamba. Manusia sebagai hamba terikat (taat, patuh, dan tunduk) hanya kepada Allah semata (Musa Asy'arie, 1992: 9-49). Sedangkan dalam tahap fungsional, alQur'an menyebutnya sebagai khalifah yang mengemban tugas untuk mewujudkan kesejahteraan di muka bumi. Manusia dalam kapasitasnya sebagai khalifah bertumpu pada kebebasan akal. Kebebasan akal ini mendorong manusia untuk dapat bergerak melalui daya kreatifitas dan memerankan fungsinya sebagai pencipta atau pembentuk sesuatu yang sesuai dengan kebutuhan, pertumbuhan, dan perkembangan masyarakat.

Elaborasi dari dua peran tersebut merupakan satu kesatuan yang tidak dapat terpisahkan. Kekhalifahan merupakan realisasi dari pengabdian kepada Tuhan. Seorang khalifah walaupun diberikan kebebasan dan kekuasaan untuk berkreasi, 
namun kebebasannya itu tidaklah mutlak. Kebebasan dan kekuasaan manusia dibatasi oleh ketentuan-ketentuan yang telah digariskan baginya dari yang diwakilinya.

Dalam konteks kebudayaan, Islam bukanlah agama yang menutup diri dari keragaman seni maupun budaya. Penyebaran Islam ke berbagai wilayah, memberikan kesempatan Islam untuk bersinggungan dengan kebudayaan dan kesenian bangsa lain yang mengandung nilai-nilai tersendiri. Islam bukanlah agama yang menentang atau meniadakan daya kreatifitas manusia dalam berkesenian dan melestarikan budaya. Islam menghargai dan mendukung daya kreatifitas manusia dalam berkesenian selama kesenian tersebut tidak bertentangan dengan aturanaturan yang telah ditetapkan Allah SWT. Ada atau tidaknya nilai dan unsur-unsur yang bertentangan dengan Islam, merupakan tolak ukur boleh tidaknya seorang Muslim melestarikan kesenian tersebut.

Manusia juga diberi fitrah (naluri) kemanusiaan oleh Allah, yaitu fitrah untuk berbeda. Perbedaan pada manusia dapat disebabkan oleh waktu, tempat, maupun oleh masing-masing pribadi tersebut. Fitrah ini kemudian mendorong manusia untuk lebih kreatif dalam menghadapi kehidupan dan dalam mengekspresikan nilai-nilai estetika. Berangkat dari fitrah tersebut (fitrah untuk berbeda) dan kemampuan manusia dalam berkreasi, maka manusia ditunjuk menjadi wakil Allah SWT di bumi dan berkewajiban bertanggungjawab terhadap setiap perilakunya. Kemampuan ini menjadikannya sebagai makhluk moral yang selamanya dituntut untuk mempertimbangkan kegiatan hidupnya dalam kriteria baik dan buruk.

Memandang kesenian sebagai proses adalah meletakkan kesenian itu sendiri dalam bingkai eksistensi hidup manusia yang merupakan jelmaan dari gagasan dan ide yang di dalamnya terkandung suatu tujuan, yaitu untuk menciptakan sesuatu yang lebih bermakna dan sesuai dengan nilai esensi Islam (tauhid). Seni merupakan ekspresi estetis yang akan mengantarkan kesadaran penikmat seni kepada ide transenden. Konsekuensi dari hal tersebut, maka semua bentuk seni termasuk seni tari dapat meningkatkan keimanan, keyakinan kepada Allah SWT, dan mengandung unsur-unsur tauhid. Adalah hal yang keliru jika semua jenis seni tari dianggap sebagai penghalang seseorang dalam beragama. Seni tari, dalam hal ini seni tari Islam justru merupakan media manusia dalam mengekspresikan nilai-nilai ilahiyah.

\section{PEMBAHASAN}

\section{Seni}

Seni merupakan ekspresi ruh dan budaya manusia dalam mengungkapkan keindahan. Seni adalah kreasi bentuk simbolis dari perasaan manusia (Dharsono Sony Kartika, 2007: 7). Dapat diartikan pula bahwa seni adalah ungkapan atau 
perwujudan nilai-nilai (Ida Ayu Dyah Maharani, 2012: 5). Seni lahir dari sisi terdalam manusia didorong oleh kecenderungan seniman kepada yang indah, apapun jenis keindahan itu. Dorongan tersebut merupakan naluri manusia, atau fitrah yang dianugerahkan Allah kepada hamba-hambanya (M. Quraish Shihab, 2000: 385). Dorongan tersebut bertransformasi dengan gagasan manusia yang melibatkan kemampuan terampil, kreatif, kepekaan indera, kepekaan hati, dan pikiran untuk menghasilkan suatu karya yang memiliki kesan indah, selaras, bernilai seni, dan lainnya (Sumanto, 2006: 5).

Melalui seni, manusia dapat memperoleh kenikmatan sebagai akibat refleksi perasaan terhadap stimulus yang diterimanya. Kenikmatan seni berbentuk kenikmatan batin (perasaan). Kenikmatan ini muncul ketika manusia menangkap dan merasakan simbol-simbol estetika dari pencipta seni, sehingga nilai seni seringkali disebut juga sebagai nilai spiritual (Rasjoyo, 1994: 1).

Pada dasarnya seni dapat dibedakan atas: (1) Seni sastra atau kesusastraan, yakni seni yang diungkapkan melalui media bahasa. (2) Seni musik merupakan seni dengan media suara. (3) Seni tari, ialah seni yang diungkapkan dengan gerakan. (4) Seni rupa merupakan seni dengan alat garis, bentuk warna, dan lain sebagainya. (5) Seni drama atau teater merupakan seni dengan alat kombinasi antara musik dengan gerakan.

\section{Seni Tari}

Seni tari merupakan salah bentuk karya seni yang berkembang dan terus dilestarikan oleh masyarakat seiring dengan perkembangan zaman. Tari adalah salah satu cabang seni yang dalam pengekspresiannya menggunakan gerak tubuh. Tari merupakan ekspresi jiwa manusia melalui gerakan ritmis yang indah dengan memperhatikan unsur ruang, waktu, dan mengandung pesan tertentu (M. Thoyibi, Yayah Khisbiyah, dan Abdullah Aly, 2003: 89). Pada mulanya seni tari merupakan bagian terpenting dari kehidupan masyarakat yang berkaitan dengan siklus hidup dan mempertahankan kelangsungan hidup manusia (Margaret Pula Elisabeth Djokaho, 2013: 1). Seni tari terbagi menjadi beberapa kelompok, yakni tari tradisional; tari nusantara; tari kreasi; dan tari kontemporer (Yayat Nursantara, 2007: 35-36).

Suatu karya seni tari dinilai indah jika memuat unsur-unsur wiraga, wirasa, wirama, dan aspek harmoni. Wiraga merupakan ungkapan secara fisik sejak dari awal hingga akhir tarian. Dalam wiraga, penari dituntut untuk hafal dengan setiap gerakan tari, menguasai teknik tari dan mampu menempatkan gerakan tari dengan posisi ruangan yang tepat. 
Wirasa pada dasarnya berhubungan dengan penjiwaan atau kemampuan penari dalam mengungkapkan emosi yang sesuai dengan isi atau tema atau karakter dari tarian yang dibawakan. Adapun wirama merupakan unsur ketajaman rasa atau kepekaan irama yang menyatu dengan gerakan tarian. Adapun aspek harmoni menekankan pada interelasi yang menyeluruh dari tarian yang dibawakan oleh penari.

Secara garis besar seni tari berfungsi sebagai: sarana upacara, hiburan, pertunjukan, dan media pendidikan (M. Jazuli, 1994: 43-46). Tari sebagai sarana upacara agama atau adat-seni tari menjadi bagian dari rangkaian suatu upacara-dapat dibedakan menjadi tiga yaitu: pertama, tarian yang digunakan dalam peristiwa keagamaan. Jenis tarian semacam ini masih dilestarikan di Bali sebagai pusat perkembangan agama Hindu. Tari-tarian ini diselenggarakan di pura-pura pada waktu tertentu dan merupakan bentuk tarian sesaji yang bersifat religius. Kedua, tarian dalam upacara adat yang berkaitan langsung dengan kepentingan masyarakat di lingkungannya (Edi Sedyawati, dkk, 1986: 179). Ketiga, tarian dalam upacara adat yang berkaitan dengan peristiwa kehidupan manusia. Menandai peristiwa kelahiran, perkawinan, penobatan, dan kematian.

Seni tari sebagai sarana hiburan digunakan dalam rangka memeriahkan suasana pesta hari perkawinan, khitan, syukuran, peringatan hari-hari besar nasional, dan peresmian-peresmian gedung. Seni tari dalam acara tersebut sebagai ungkapan rasa senang dan bersyukur yang diharapkan akan memberikan hiburan bagi orang lain (F. Sekarningsih dan Heny Rohayani, 2006: 5). Kesenangan terletak pada hubungan yang terdapat antara obyek keindahan dengan manusia. Pada umumnya manusia merasa senang karena obyek yang dinilai indah dapat ditangkap dengan indra dan memenuhi selera manusia (Sumandiyo Hadi, 2005: 16).

Seni tari sebagai sarana pertunjukan atau teatrikal merupakan tarian yang mempertunjukkan sesuatu yang dinilai seni, namun tetap terdapat unsur untuk menarik perhatian; memberikan kepuasan jiwa; kesan; dan wawasan baru (M. Jazuli, 1994: 43-46). Tari teatrikal hanya dipertunjukkan dan diselenggarakan ditempat-tempat pertunjukan khusus, misalnya gedung pertunjukan; panggung; maupun arena terbuka (R. M. Soedarsono, 1976: 12).

Seni tari sebagai media pendidikan. Seni tari merupakan sarana pendidikan etika, estetika, dan pandangan hidup para putra dan putri raja. Melalui seni tari, mereka diajarkan untuk memiliki rasa sabar; halus; telaten; serta kepekaan perasaan. Sifat sabar akan diperoleh pada saat melakukan gerak dasar secara berulang-ulang dan terus menerus. Halus diperoleh pada saat melakukan gerak tari yang selalu dituntut sesuai dengan 
hitungan tari dan penuh dengan penghayatan. Ketelatenan didapat dari cara melakukan gerak tari yang harus dilatih terus-menerus dari hasil pengitimasian secara rinci untuk dapat dilakukan atau dipraktekkan. Selain itu, anak yang belajar menari sejak dini akan lebih memiliki rasa percaya diri, berani, terampil, peka terhadap irama maupun iringan, berestetika, dan beretika (Supriyanti,2003: 101-102)

Seni tari juga berfungsi sebagai media hubungan sosial atau pergaulan (seni tari dapat digunakan sebagai media pemersatu masyarakat). Pada hakikatnya semua seni termasuk seni tari berfungsi sebagai media komunikasi. Seni tari mempunyai keistimewaan dalam menyampaikan pesanpesannya yaitu berupa gerakan ekspresi manusia yang lebih mudah ditangkap dan dipahami melalui panca indra manusia daripada bentuk seni yang lain (Sumandiyo Hadi, 2005: 19).

Dalam menyajikan seni tari harus memuat elemen-elemen yang teraktualisasi di dalam tari. Bentuk penyajian tari adalah wujud keseluruhan dari suatu penampilan yang didalamnya terdapat aspek-aspek atau elemen-elemen pokok yang ditata dan diatur sedemikian rupa sehingga memiliki nilai estetis yang tinggi. Elemen-elemen tersebut merupakan satu kesatuan yang tidak dapat dipisahkan karena elemen tersebut memiliki fungsi yang saling mendukung dalam sebuah pertunjukan tari (R. M. Soedarsono, 1978:
21-36). Dengan kata lain, tari bukan hanya sekedar keselarasan antara bentuk gerakan seluruh tubuh yang ditata sesuai dengan irama musik, namun seluruh ekspresi itu harus mengandung maksud "isi" tari yang dibawakan (Supriyanti, 2003: 93-103). Elemen-elemen pokok tersebut meliputi: gerak tari, desain lantai, desain atas, musik atau iringan, desain dramatik, tema, tujuan atau pesan, tata rias, tata busana, tempat pertunjukan, dan perlengkapan tari.

\section{Seni Dalam Pandangan Islam}

Sekuler adalah salah satu ciri dari peradaban Barat. Dengan kata lain, karakter budaya barat merupakan budaya yang bebas nilai (sekuler). Sekulerisme tidak hanya berkembang dalam ranah agama, namun juga pada ranah estetika. Paham sekulerisme memberikan kebebasan sepenuhnya kepada seorang seniman untuk berekspresi tanpa ada batasan nilai maupun norma. Budaya dan seni adalah persoalan duniawi yang tidak boleh dicampuri oleh agama. Dengan kata lain, kesenian dalam konteks kebudayan barat merupakan seni yang bebas nilai.

Peradaban Barat sangat kontras dengan peradaban Islam. Jika peradaban Barat sangat erat kaitannya dengan sekularisme, peradaban Islam justru tidak mengenalnya. Seluruh kegiatan manusia baik dalam aspek sosial, politik, hukum, ekonomi, kebudayaan, dan kesenian harus berlandaskan tauhid. Seluruh aspek 
kehidupan itu harus mampu menghantarkan pelakunya pada kebesaran dan kekuasaan Allah SWT.

Pada aspek berkesenian, seni dalam pandangan Islam merupakan manifestasi pengalaman estetika dalam jiwa manusia. Seni lahir dari sisi terdalam manusia didorong oleh kecenderungan seniman kepada yang indah, apapun jenis keindahan itu (M. Quraish Shihab, 2000: 385). Kesenian dalam berbagai wujudny amerupakan bentuk aktualisasi eksistensi manusia dalam berbudaya. Dorongan tersebut merupakan naluri manusia atau fitrah yang dianugerahkan Allah kepada manusia. Kemampuan manusia dalam berkesenian dan berekspresi merupakan salah satu unsur yang membedakan antara manusia dengan makhluk yang lain.

Melalui seni, manusia dapat merasakan kenikmatan (nikmat batin) sebagai akibat dari refleksi perasaan terhadap stimulus yang diterimanya. Kenikmatan ini muncul ketika manusia dapat menangkap dan merasakan simbol-simbol estetika dari pencipta seni. Oleh karena itu, seringkali dikatakan bahwa nilai seni sebagai nilai spiritual (Rasjoyo, 1994: 1).

Al-Qur'an menyebut bahwasanya Islam adalah agama fitrah. Konsekuensi dari hal tersebut, Islam mendukung kesenian selama ekspresi dan manifestasi kesenian tersebut lahir dan mendukung fitrah manusia yang suci. Oleh karena itu, Islam bertemu dengan seni dalam jiwa manusia (Syamsul Hidayat, 2001: 27).

Tujuan dan fungsi seni dalam Islam merupakan sebagai penopang dan pembantu ajaran al-Qur'an, yakni menghantarkan pada kesadaran terhadap Allah swt melalui keindahan bentuk, warna, dan bunyi yang memikat. Dengan kata lain, seni mampu menghantarkan manusia pada yang tak terhingga dan bertindak sebagai sarana untuk mencapai Yang Maha Benar (Sayyed Hossein Nars, 1994: 219).

Prinsip dasar estetika (keindahan) adalah pandangan dunia tauhid. Dengan demikian, estetika merupakan bagian dari ekspresi tauhid-inti ajaran Islam-yang membawa kesadaran kepada ide transenden. Pengalaman estetik akan tertuang dalam bentuk seni (Suharjianto, 2001: 6). Seni yang diekspresikan melalui gerakan, akan menciptakan gerakan tari yang indah. Segala sesuatu yang tidak ada di alam adalah transenden. Adapun yang memenuhi syarat transenden hanya Allah. Dengan demikian, seni merupakan ekspresi estetis yang akan mengantarkan kesadaran penikmat seni kepada ide transenden. Agama tanpa seni menjadi vulgar dan tanpa arah. Hakekat pengalaman estetik (seni) dan pengalaman keagamaan-dalam konsep filsafat Islamterletak pada dimensi ontologis dan spiritual yang bersifat tunggal, dus tidak ada kontradiksi antara keduanya, bahkan saling memperkaya rohani seseorang. Agama dan 
seni sama-sama mampu mentrasendir cahaya keindahan Ilahi dan tanda-tanda kebesaran Allah yang terpantul pada ciptaan-Nya (Musa Asy'arie, 1999: 135).

Seni budaya dan ekspresinya merupakan bentuk aktualisasi eksistensi manusia. Seni budaya merupakan suatu proses kreatifitas manusia dalam kapasitasnya sebagai khalifah-bertumpu pada kebebasan akal dalam bergerak dan kebebasan memerankan fungsinya sebagai pencipta serta pembentuk kebudayaan itu sendiri-dan sebagai hamba yang senantiasa harus taat, patuh, dan tunduk kepada Allah semata. Elaborasi dari dua peran tersebut, merupakan satu kesatuan yang tidak terpisahkan. Kekhalifahan merupakan realisasi dari pengabdian kepada Allah. Walaupun seorang khalifah diberikan kebebasan dan kekuasaan untuk berkreasi, namun kebebasannya tidaklah mutlak. Kebebasan dan kekuasaannya dibatasi oleh ketentuan-ketentuan yang telah digariskan baginya dari yang diwakilinya (Musa Asy'arie, 1999: 9-49).

Suatu kesenian dapat dikatakan seni Islam atau seni yang islamis, jika hasil seni itu mengungkapkan pandangan hidup kaum Muslimin (konsep tauhid) walaupun seniman yang membuat objek seninya tidak seorang (M. Abdul Jabbar Beg, 1981: 2-3). Ungkapan artistik seni Islam memiliki karakteristik yang membedakan dengan seni yang lainnya, yaitu: pertama, seni Islam bercirikan abstrak dan mujarat. Alam dalam pandangan seni Islam merupakan salah satu kreasi seni Allah swt yang dapat dirasa dan diraba. Berbeda dengan seni figural yang memandang alam hanya ilusi yang dinafikkan.

Kedua, seni Islam bercirikan struktur modular. Artinya dalam karya seni Islam senantiasa di bangun dari atau bentuk-bentuk yang lebih kecil yang pada akhirnya bergabung menjadi bentuk yang lebih komplek.

Ketiga, seni Islam bercirikan gabungan berurutan. Artinya dalam berbagai bentuknya-seni suara, ruang, dan gerak-seni Islam tersusun dari komponen kecil yang bergabung secara berurutan. Gabungan berurutan yang lebih besar tesebut dalam kenyataannya tidak menafikan keberadaan komponen yang lebih kecil. Justru gabungan-gabungan tersebut di sambung dengan komponen yang lebih besar yang membentuk gabungan yang lebih kompleks.

Keempat, seni Islam bercirikan perulangan. Artinya dalam berbagai coraknya, karya seni Islam mengandung model perulangan yang berupa perulangan motif, struktur modular, maupun kombinasi berurutan. Manifestasi dari ciri ini dapat dilihat dalam al-Qur'an. Hal ini menunjukkan bahwa seni Islam merupakan karya maha agung yang menakjubkan, karena menciptakan suatu perulangan yang 
disertai keseragaman makna dan bunyi merupakanhal yang tidak mudah.

Kelima, seni Islam bercirikan dinamis. Artinya dalam karya-karya seni Islam senantiasa melalui lingkungan masa. Seni yang meliputi lingkungan masa adalah seni sastra dan seni musik. Sedangkan seni yang meliputi lingkungan ruang adalah seni tampak atau bina, yaitu arsitektur (Sayyed Hossein Nasr, 2004: 271-272).

Terdapat batasan unsur seni yang sesuai dengan nilai Islam, yakni harus memuat unsur benar, baik, dan bagus (Sidi Gazalba, 1988: 118). Sesuatu yang baik, namun tidak benar-mendukung fitrah (menegakkan akidah tauhid)-tidak dapat diterima oleh Islam. Demikian pula dengan sesuatu yang bagus, namun tidak benar pun tertolak dalam pandangan Islam. Sehingga, sesuatu yang bagus menurut konsepsi Islam pastilah yang bersifat baik dan sesuatu yang baik pastilah sesuai dengan ukuran kebenaran (Sidi Gazalba, 1988: 119). Batasan kebenaran dalam Islam tidak terletak pada akal namun pada ayat-Nya. Konsekuensinya, selama suatu kesenian tersebut memuat unsur-unsur baik; benar; dan bagus menurut Islam, maka kesenian tersebut boleh dilestarikan.

Terdapat beberapa norma dalam Islam yang mengatur dalam berkesenian, yaitu: (1) Tidak ada nilai unsur-unsur yang bertentangan dengan Al-Qur'an. (2) Tidak melukis sesuatu yang bernyawa dan pornografi. (3) Menghindari tasyabuh (meniru-niru) dan tabarruj (memamerkan kecantikan). (4) Selalu menjalin tali persaudaraan dengan mengedepankan toleransi. (5) Dilarang menciptakan hikayat yang menceritakan dewa-dewa dan mengkritik Allah SWT. (6) Dilarang menampilkan drama dan film yang melukiskan kekerasan, kebencian, dan kekejaman.

\section{Seni Tari Dalam Pandangan Islam}

Tauhid mempunyai peran yang sangat penting dalam mencapai tujuan penciptaan manusia. Manusia yang dalam aktualisasi kehidupan sehari-harinya mampu mengaplikasikan nilai-nilai ilahiyah. Tauhid merupakan identitas pada peradaban Islam, yang mengikat semua unsurnya bersamasama dan menjadikan unsur-unsur tersebut sebagai suatu kesatuan integral dan organis. Kalimat tauhid yang paling singkat, namun memiliki makna yang dalam adalah laa Ilaha illa Allah. Inti kalimat ini adalah membebaskan manusia dari ketundukan terhadap selain Allah dan hanya menyembah Allah swt. Semua risalah rasul hanya memiliki satu esensi yang memuat dua unsur, yaitu tauhid dan moralitas (Masmedia Pinem, 2012: 277). Tauhid merupakan penegasan keesaan Allah dan moralitas alQur'an merupakan sikap untuk melakukan perbuatan yang baik dan menjauhi perbuatan yang buruk. 
Tauhid merupakan esensi dari ajaran Islam. Konsekuensi dari hal ini, maka tauhid menjadi esensi pengetahuan; peradaban; dan sekaligus pandangan dunia (worldview). Esensi kebudayaan dan peradaban Islam adalah Islam itu sendiri dan esensi Islam tidak lain adalah tauhid. Hal ini bermakna bahwa tauhid merupakan prinsip penentu pertama dalam segala aspek kehidupan manusia, termasuk dalam berkesenian. Seni merupakan fitrah manusia. Seni merupakan bentuk aktualisasi ekspresi manusia. Seni dalam Islam bukan hanya sekedar mengajarkan moral, tetapi harus mengandung tauhid. Artinya, untuk menyampaikan pesan-pesan tauhid melalui kesenian harus tetap berada dalam koridor moral. Ekspresi keindahan yang dituangkan melalui gerakan dalam seni ruang, adalah tarian. Ilmu seni tari diperkenalkan pertama kali oleh al-Farabi (872-950) melalui kitabnya yang berjudul ar-raqsu waz-zafnu (kitab tentang tari dan gerak kaki). Pengaruh kitab ini masih dapat dilihat dalam tari zapin, tari tradisional dari Riau.

Seni tari Islam berbeda dengan seni tari Barat. Seni tari Islam dalam aplikasinya selalu berpijak pada norma-norma Islam. Nilai-nilai ilahiyah merupakan worldview bagi pencipta tari, penari, maupun penikmat tari. Tarian Islam menawarkan rasa kepuasan batiniah (spriritual) bagi manusia. Melalui materi tarian Islam yang bernilai positif, manusia dapat melihat dan merasakan kekuasaan Allah. Hal ini menciptakan perasan nyaman, tenang, mendekatkan kepada Allah, mengingatkan manusia untuk banyak berdzikir, menuntun manusia untuk memikirkan ayat-ayat kauniyah, menuntun untuk mengingat nikmat dan ciptaan Allah SWT, mengajarkan sikap, dan memiliki keyakinan dan komimen yang kokoh.

Budaya tari dalam masyarakat Muslim merupakan manifestasi artistik-disajikan dalam bentuk tertentu-ajaran Islam tentang tauhid (keesaan Allah). Seni tari dapat dikatakan seni tari Islam atau seni tari yang islamis, jika seni tari tersebut mengungkapkan pandangan hidup Muslim (konsep tauhid) walaupun pencipta tarian tersebut bukanlah seorang Muslim. Tauhid adalah esensi Islam yang mencakup seluruh aktifitas manusia. Tauhid adalah denominator bersama bagi semua seniman yang berpegang pada dunia Islam.

Peradaban Islam dengan berbagai wujudnya-termasuk seni tari-tersusun dari unsur-unsur tauhid yang saling terkait dan berkesinambungan, baik itu nilai-nilai ilahiyah (rububiyah; uluhiyah; maupun tauhid asma wa sifat) sebagai landasan etisnormatif, nilai-nilai insaniyah (antropososiologis) dan alamiah (kosmologis) sebagai basis praksis operasionalnya.

Nilai tauhid rububiyah dalam ekspresi estetis seni tari terlihat dari aspek visualnya. Aspek visual pada tari Islami cenderung memiliki makna filosofi yang tinggi. 
Gerakan tari Islami dalam hal ini tari Zapin yang didominasi gerakan berputar melambangkan gerakan planet-planet yang mengelilingi matahari sebagai pusat orbitnya. Gerakan berputar memberikan pelajaran kepada manusia tentang ketundukan alam semesta dengan kehendak Allah swt sekaligus sebgai pembuktian bahwa Allah Maha Besar, Maha Pencipta, dan Maha Pengatur.

Nilai tauhid uluhiyah disimbolkan pada pemilihan warna putih atau hijau pada kostum yang dikenakan. Kostum kain warna putih melambangkan kain kafan yang mengingatkan manusia pada kematian dan warna hijau melambangkan hari akhir (surga). Kematian yang khusnul khatimah akan menghantarkan manusia pada surga yang abadi. Surga hanya akan diperoleh manusia yang dapat beramal shaleh sesuai syariat dan ikhlas hanya untuk Allah SWT. Gerakan tari yang melambangkan uluhiyah juga terlihat dalam gerakan berputar ke arah kiri. Gerakan berputar ke arah kiri melambangkan putaran tawaf di Ka'bah. Tawaf merupakan bagian dari rukun haji yang merupakan salah satu dari rukun Islam. Gerakan berputar ke arah kiri menyadarkan manusia untuk hanya berserah diri kepada Allah SWT. Pengertian ini merupakan makna dari laa ilaaha illallah (tidak ada yang berhak diibadahi kecuali Allah).

Tauhid asma wa sifat merupakan tauhid tentang beriman kepada nama-nama
Allah dan sifat-sifat Allah. Keyakinan bahwa Allah Maha Melihat, Maha Mendengar, Maha Pemberi Balasan melahirkan kesadaran pada diri manusia untuk tetap berada dalam koridor syariat Islam. Kesadaran pada sifat-sifat Allah mendorong penari untuk tidak menampakkan aurat dan bercampur antara penari wanita dengan penari pria.

Nilai insaniyah terdapat dalam musik iringan seni tari yang berupa iringan lagam gamelan dan shalawatan. Melalui shalawatan, para penikmat seni diajak untuk mendengarkan dan mengikuti pujian-pujian kepada nabi Muhammad saw. Lirik dan alat musik gamelan melambangkan dakwah wali songo yang melakukan dakwah kultural dengan budaya jawa. Gamelan mengingatkan kewajiban manusia untuk senantiasa berdakwah kepada diri sendiri, keluarga, dan masyarakat sekitar.

\section{KESIMPULAN}

Seni dalam pandangan Islam merupakan manifestasi pengalaman estetika dalam jiwa manusia. Seni tari Islam berbeda dengan seni tari Barat. Seni tari Islam dalam aplikasinya selalu berpijak pada normanorma Islam. Nilai-nilai ilahiyah merupakan worldview bagi pencipta tari, penari, maupun penikmat tari. Tarian Islam menawarkan rasa kepuasan batiniah (spriritual) bagi manusia. Melalui materi tarian Islam yang bernilai positif, manusia dapat melihat dan 
merasakan kekuasaan Allah. Hal ini menciptakan perasan nyaman, tenang, keinginan mendekatkan kepada Allah, mengingatkan manusia untuk banyak berdzikir, menuntun manusia untuk memikirkan ayat-ayat kauniyah, menuntun untuk mengingat nikmat dan ciptaan Allah swt, mengajarkan sikap, dan memiliki keyakinan dan komimen yang kokoh.

\section{DAFTAR PUSTAKA}

Asy'arie, M. (1992). Manusia Pembentuk Kebudayaan dalam Al-Qur'an. Yogyakarta : LESFI.

Asy'arie, M. (1999). Filsafat Islam: Sunnah Nabi Dalam Berpikir. Yogyakarta: Lesfi.

Beg, M. A. J. (1981). Seni dalam Peradaban Islam. Terj. Yustiono dan Edi Sutriyono. Bandung: Pustaka.

Djokaho, M. P. E. (2013). "Pergeseran Fungsi Tari Ja'I Dari Ritual Ke Profan Di Kota Kupang". Tesis Program Studi Pendidikan Seni. Bandung: Universitas Pendidikan Indonesia.

Gazalba, S. (1988). Islam dan Kesenian: Relevansi Islam dengan Seni-Budaya Karya Manusia. Jakarta: Pustaka alHusna.

Hadi, S. (2005). Sosiologi Tari. Yogyakarta: Pustaka Hidayat.

Hidayat, S. (2001). Studi Kritis Hadith Tentang Seni Lukis Dan Pahat. Jurnal Suhuf 1.

Jazuli, M. (1994). Telaah Teoritis Seni Tari. Semarang: IKIP Semarang.

Maharani, I. A. D. (2012). Arti Seni dan Perkembangan Nilai Seni di Indonesia. Skripsi Fakultas Seni Rupa dan Desain. Bali: Institut Seni Indonesia Denpasar.

Nars, S. H. (1994). Spiritualitas dan Seni Islam. Terj. Sutejo, Bandung: Mizan.
Nars, S. H. (2004). Intelegensi dan Spiritualitas Agama-Agama. Terj. Suharsono dkk. Jakarta: Inisiasi Press.

Nursantara, Y. (2007). Seni Budaya Untuk SMA Kelas X. Bekasi: Erlangga.

Pinem, M. (2012). Ekspresi Seni dalam Islam Kajian atas Pemikiran Ismail Raji Al-Faruqi. Jurnal Suhuf, 5(2). 271-287.

Qardawi, Y. (2000). Haqiqat al-Tawhid. Terj. Musyaffa. Jakarta: Rabbani Press.

Rasjoyo. (1994). Pendidikan Seni Rupa untuk SMU Kelas I. Jakarta: Erlangga.

Sedyawati, E., et al. (1986). Seni Pertunjukan Indonesia di Era Globalisasi, Yogyakarta: Gajah Mada University Press.

Sekarningsih, F., \& Rohayani, H. (2006). Kajian Lanjutan Pembelajaran Tari dan Drama I. Bandung: UPI Press.

Shihab, M. Q. (2000). Wawasan al-Qur'an. Bandung: Mi

Soedarsono, R. M. (1976). Pengantar Pengetahuan Tari. Yogyakarta: Akademi Seni Tari Indonesia.

Soedarsono, R. M. (1978). Pengantar dan Pengetahuan Komposisi Tari. Yogyakarta: Akademi Seni Tari Indonesia.

Kartika, S., \& Dharsono. (2007). Kritik Seni. Bandung: Rekayasa Sains.

Suharjianto. (2001). Estika Dalam Pandangan Isma'il Raji al-Faruqi. Jurnal Suhuf, 1.

Sumanto. (2006). Pengembangan Kreativitas Seni Rupa Anak TK. Jakarta: Direktorat Jendral Perguruan Tinggi Direktorat Pendidikan Tenaga Kependidikan dan Tenaga Perguruan Tinggi.

Supriyanti. (2003). Suatu Penawaran Berkesenian. dalam M. Thoyibi, Yayah Khisbiyah, dan Abdullah Aly, Sinergi Agama dan Budaya Lokal: Dialektika Muhammadiyah dan Seni Lokal, Surakarta: Muhammadiyah University Press. 